\title{
talenta

\section{Response on Growth and Production of Vetiver (Vetiveria zizanioides $L$.) on Gibberelin Under Salinity Stress Conditions}

\author{
Aisar Novita ${ }^{*}$, Nini Rahmawati ${ }^{2}$ Fitra Syawal Harahap ${ }^{3}$, Hilwa Walida, \\ Abdul Rahman Cemda ${ }^{1}$, Fitria ${ }^{1}$, Hilda Julia ${ }^{1}$, Rini Susanti ${ }^{1}$, Bayu \\ Pratomo $^{4}$, Silvia Nora ${ }^{5}$, Merlyn Mariana ${ }^{5}$ and Arie Hapsani Hasan Basri ${ }^{5}$ \\ ${ }^{1}$ Department of Agrotechnology, Faculty of Agriculture, University of Muhammadiyah Sumatera Utara, \\ Medan, Sumatera Utara, Indonesia \\ ${ }^{2}$ Department of Agrotechnology, Faculty of Agriculture, Universitas Sumatera Utara, Medan, Sumatera \\ Utara, Indonesia \\ ${ }^{3}$ Department of Agrotechnology, Faculty of Sains dan Teknologi, Universitas Labuhanbatu,, \\ Rantauprapat, Sumatera Utara, Indonesia \\ ${ }^{4}$ Department of Agrotechnology, Faculty of Agro Technology, University of Prima Indonesia, Medan, \\ Sumatera Utara, Indonesia \\ ${ }^{5}$ Politeknik Pembangunan Pertanian, Kabupaten Deli Serdang, Sumatera Utara, Indonesia
}

\begin{abstract}
Vetiver (Vetiveria zizanioides L.) plants are able to protect the soil from erosion and are tolerant of salinity stress. However, at high salinity levels, vetiver plants show a decreasing growth. The application of gibberelin is expected to increase the growth of vetiver in salinity stress conditions. The purpose of this study was to evaluate the growth responsiveness and production of vetiver the application of gibberelin under salinity stress conditions. This research was conducted in the green house of the Faculty of Agriculture, Universitas Sumatera Utara, Medan. This study used a non-factorial completely randomized design, namely the salinity stress (S) which consisted of 3 levels, each treatment was repeated 3 times, so that 9 treatment combinations were obtained: the concentration of gibberelin was 0 (no treatment), $50 \mathrm{ppm}$ and $100 \mathrm{ppm}$.
\end{abstract}

Keywords: gibberelin, salinity, Vetiveria zizanioides

\section{Introduction}

Vetiver have a fragant aroma and high fixative properties, so they are widely used as raw materials for industries such as making perfumes, cosmetics, deodorants, soaps, medicines, and mosquito repellents. Hence the economic value of vetiver oil is very high. However, vetiver plant also functions as an erosion inhibitor and soil rehabilitation, so that land is increasingly limited for planting vetiver seedlings intended for oil vetiver production [1].

\footnotetext{
*Corresponding author at: Department of Agotechnology, Faculty of Agiculture, University of Muhammadiyah Sumatera Utara, Jl. Muhatar Basri No.3 Medan Sumatera Utara, 20238, Indonesia

E-mail address: aisarnovita@umsu.ac.id
} 
Vetiver (Vetiveria zizanioides L.) plants also function as an inhibitor of soil erosion and rehabilitation, so that land is increasingly limited for planting vetiver seedlings intended for oil vetiver production. Vetiver vetiver plants are metal hyperaccumulator plants that have high absorption or accumulation properties of heavy metals in plant tissue. This plant is very tolerant of drought and flood, frost, heat, extreme soil $\mathrm{pH}, \mathrm{Al}$ and $\mathrm{Mn}$ toxicity, and very tolerant of various metals such as $\mathrm{As}, \mathrm{Cd}, \mathrm{Cu}, \mathrm{Cr}$, and $\mathrm{Ni}[2]$.

The results of the research [3] stated that compared to $\mathrm{NaCl}$ treatment, $200 \mathrm{mM} \mathrm{NaCl}$ for 18 days decreased leaf elongation, photosynthesis and decreased relative growth rate of around $44 \%$, indicating that vetiver has the ability to maintain growth and lengthening of leaves below. conditions of high salinity. These results indicate that $\mathrm{Na}+$ can be beneficial for the growth of vetiver.

Soil that contains salinity becomes more saline so that the soil cannot absorb water from the soil. This is because plants or plants contain various concentrations of ions (salts) which make natural water flow from the soil to the plant roots when the soil has high enough saline, it can inhibit the movement of water from plant roots to be pulled back into the soil so that the plant cannot take enough water for the growth process. If the concentration of residual salinity in the soil is high enough, plants will wither and die regardless of the content of water given [4].

Gibberelin reduces the inhibitory $\mathrm{NaCl}$ effect on several parameters of growth and pigments of photosynthetic in Roselle by inducing enzyme activity and increasing relative water content and therefore Gibberelin helps in plant tolerance to salt stress [5]. Based on this, it is deemed necessary to conduct research on the growth and production response of vetiver on Gibberelin application under salinity stress conditions.

\section{Materials and Methods}

The materials used in this study were 6-month-old vetiver seeds as plant material, salin soil 4 dSm-1 from Percut Sei Tuan, deltametrin $25 \mathrm{~g} / \mathrm{l}$, Gibberelin A3 (GA3). The tools used in this research are polybags, HPLC, refractometer, spectrometer, plastic color labels, scissors, digital scales, calculators, stationery, microscopes, leaf area meters, chlorophyll meters. This research used non factorial Randomized Block Design, The Gibberelin (G) which consisted of 3 levels: Gibberelin concentration of 0 (no treatment), $50 \mathrm{ppm}$ and $100 \mathrm{ppm}$. Each treatment was repeated 3 times, then obtained 9 treatment units.

In research implementation, land preparation was first carried out. The land is cleared of weeds and trash until it was clean. The polybags are filled with Salin soil that has been measured for salinity (4 dSm-1). After that, order the seeds Ordering seeds. the seeds ordered are seeds of the same age and size. The seeds used in this study came from 6 months old vetiver seeds. After placing an order for seeds, the next activity is land preparation, the land is cleared of weeds and 
trash until it was clean. The polybags are filled with Salin soil (4 dSm-1). After that, order the seeds Ordering seeds. the seeds ordered are seeds of the same age and size. The seeds used in this study came from 6 months old vetiver seeds. The next step was preparation of seeds, the seeds of vetiver were taken with the same growth, not attacked by pests and diseases. If the plants have been planted, a marker was placed on each crop plot. In planting seeds, the sorted seeds with the same growth are planted in salin soil. After that, Gibberellin is applied according to the respective treatment level, namely without giving gibberelin, $50 \mathrm{ppm}$ (done by weighing $50 \mathrm{mg}$ of gibberelin then diluting and dissolving into 1 liter of water), $100 \mathrm{ppm}$ (done by weighing $100 \mathrm{mg}$ of gibberelin then diluting and dissolving into the water as much as 1 liter). Gibberellin is applied by spraying it on the leaves until the leaf surface is exposed. the application of gibberellin A3 (GA3) was carried out at 2 weeks after planting (WAP) according to the respective concentration levels. In cultivation, Seeds are doused with sufficient distilled water (if necessary) to prevent salt accumulation and increase in concentration in polybags.

The observed parameters were leaf area $(\mathrm{cm} 2)$, dry weight of leaves $(\mathrm{g})$, content of chlorophyll $(\mu \mathrm{g} / \mathrm{ml})$ and number of stomata $(\mathrm{mm} 2)$. Leaf area measurements was 6 WAP. Calculated using a leaf area meter. The observed leaves were the largest, medium and smallest leaves that had fully opened. The dry weight test was carried out by drying in an oven at $65 \mathrm{oC}$ for 24 hours to obtain the dry weight of seeds [6]. Chlorophyll content analysis was carried out at the Central Laboratory, Faculty of Agiculture, University of North Sumatra, Medan. Content of Chlorophyll Levels Based on the Winterman de Mots Method. Vetiver leaf samples were weighed as much as $1 \mathrm{~g}$ and mashed in a mortar. The sample was extracted by adding $50 \mathrm{~mL}$ of $96 \%$ alcohol until all chlorophyll was dissolved (5 minutes). Then, extract is filtered with filter paper. The filtrate obtained is put into a $100 \mathrm{~mL}$ volumetric flask and then $96 \%$ alcohol is added to the volume of $100 \mathrm{~mL}$. The solution was measured for chlorophyll using a spectrophotometer at a wavelength of $649 \mathrm{~nm}$ and $665 \mathrm{~nm}$. The results of the absorbance value measurement are then converted into $\mathrm{mg} / \mathrm{L}$ units using the formula below:

Total Chlorophyll $(\mathrm{mg} / \mathrm{L})=(20 \times$ OD649 $+6.1 \times$ OD645 $)$

Chlorophyll a $(\mathrm{mg} / \mathrm{L})=(13.7 \times$ A665) $-(5.67 \times$ A649)

Chlorophyll b $(\mathrm{mg} / \mathrm{L})=(25.8 \times \mathrm{A} 649)-(7.7 \times \mathrm{A} 665)$.

Observation of the number of stomata was carried out using microscopy at the age of 8 WAP at the Disease Laboratory, Faculty of Agiculture, University of North Sumatra, Medan. The method used to observe the stomata on the leaf surface is the replica method, which is as follows: first sterilization of the leaves with sodium hypochloride is then rinsed with distilled water, then the leaves are smeared with transparent nail polish. Let it dry (wait) 10-15 minutes. After drying, the nail polish spread is affixed with a transparent colored tape and flattened, then slowly peeled off. 
The result of the peel is then affixed to the glass preparation. Observation of the number of stomata was carried out using a microscope.

\section{Results and Discussion}

\subsection{Leaf Area}

Gibberelin treatment had a significant effect on leaf area variables. The results of the different test results in the average leaf area in the gibberelin treatment can be seen in Table 1. Gibberelin gave a very significant effect on the average leaf area. Gibberelin treatment of $100 \mathrm{ppm}(\mathrm{G} 2=$ $36.58 \mathrm{~cm} 2)$ and $50 \mathrm{ppm}(\mathrm{G} 1=30.55 \mathrm{~cm} 2)$ increased leaf area compared without giving Gibberelin $(\mathrm{G} 0=22.96 \mathrm{~cm} 2)$ for 6 WAP observations.

Table 1. Leaf Area of Vetiver on the Application of Gibberelin Under Salt Stress Conditions

\begin{tabular}{cc}
\hline $\begin{array}{c}\text { Treatment of Gibberelin } \\
\text { (ppm) }\end{array}$ & $\begin{array}{c}\text { Leaf Area } \\
\left(\mathbf{c m}^{\mathbf{2}}\right)\end{array}$ \\
\hline G0 (0) & $22.96 \mathrm{c}$ \\
G1 (50) & $30.55 \mathrm{~b}$ \\
G2 (100) & $36.58 \mathrm{a}$ \\
\hline
\end{tabular}

Note: Numbers in the same column and row followed by the same letter are not significantly different at the $5 \%$ level based on the LSD test

In this study, gibberellin significantly affected the enlargement of leaf area (Table 1). Giving gibberelin concentrations up to $100 \mathrm{ppm}$ gave the highest leaf area, then decreased in cytokinin concentrations of $50 \mathrm{ppm}$. The leaf area of vetiver plants that were not given gibberellin $(0 \mathrm{ppm})$ was lower than that of plants treated with gibberellin. Gibberellins can independently increase the leaf area so that the leaf area increases. The same thing was stated by [7] in his research results that by giving gibberelin treatment it can increase the leaf area of wheat plants. In line with this study, [8] state that gibberellin has been known as a growth trigger that has a broad influence on plants, from germination to harvest and most importantly on cell division and cell enlargement. that gibberellin can increase germination, leaf expansion, stem extension and flowering in Arabidopsis plants. Gibberellin had a significant effect on the number of Gbranches and leaves, according to the work of the auxin and cytokinin hormones. Gibberellin induces enzymes that soften cell walls and increase auxin levels. The formation of IAA in the shoot apical meristem will stimulate the formation of leaves.

\subsection{Dry weight of leaves}

Gibberelin treatment had a very significant effect on leaf dry weight variables. The results of the different test results in the average dry weight of the leaves in the gibberelin treatment can be seen in Table 2. 
Table 2. Dry Weight of Vetiver on The Application of Gibberelin Under Salt Stress Conditions

\begin{tabular}{cc}
\hline $\begin{array}{c}\text { Treatment of Gibberelin } \\
\text { (ppm) }\end{array}$ & $\begin{array}{c}\text { Dry Weight of Leaves } \\
\text { (g) }\end{array}$ \\
\hline G0 (0) & $3.59 \mathrm{c}$ \\
G1 (50) & $4.20 \mathrm{~b}$ \\
G2 (100) & $4.61 \mathrm{a}$ \\
\hline
\end{tabular}

Note: Numbers in the same column and row followed by the same letter are not significantly different at the $5 \%$ level based on the LSD test

Gibberelin gave a very significant effect on the average dry weight of the leaves. Gibberelin treatment of $100 \mathrm{ppm}(\mathrm{G} 2=4.61 \mathrm{~g})$ and $50 \mathrm{ppm}(\mathrm{G} 1=4.2 \mathrm{~g})$ increased the dry weight of leaves compared without giving Gibberelin $(\mathrm{G} 0=3.59 \mathrm{~g})$ for 6 WAP observations. Gibberelin in salinity stress conditions can increase leaf dry weight, this is because the hormone Gibberelin is able to stimulate metabolic activity, thereby increasing the growth and accumulation of biomass (dry weight). This happens because the ability of plants to collect organic compounds derived from the nutrients given is high enough which results in dry weight gain.

In this research, the application of gibberellin at various concentrations had a significant effect on dry weight of leaves. Plant dry weight reflects the nutritional status in the plant. The increase in plant dry weight indicates that the plant is experiencing increased growth and development. Plant dry weight is related to the relocation of photosynthetic processes stored for the formation of plant material, plant dry weight illustrates the balance between photosynthetic utilization and respiration. Larger photosynthate will allow the formation of larger plant organs and then produce greater dry weight production. The provision of gibberellin stimulates the metabolic activity of plants, so that cell differentiation activities increase and the process of growth and tissue development increases so that the dry weight of plants also increases. [9] The effect of gibberellin is seen to be more pronounced in stressful conditions. As with stress conditions due to salinity stress, it is hoped that giving gibberellins to rice plants from seed can be applied to get better results. The response due to the accumulation of high salt content and its effect on the administration of gibberellin growth regulators will also be different, so that an increase in germination, growth and yield of rice plants will be seen due to the effect of giving gibberellin growth regulators with the right concentration.

\subsection{The content of chlorophyll}

Gibberellin treatment had no significant effect on the variable content of chlorophyll. The results of the different test results for the average content of chlorophyll in the gibberelin treatment can be seen in Table 3 .

Gibberelin gave no significant effect on the amount of chlorophyll. Salinity affects not only leaf morphology and transpiration rate but also leads to a reduction in the total chlorophyll content as it increases salt concentration. 
Table 3. The Content of Chlorophyll of Vetiver on The Application of Gibberelin Under Salt Stress Conditions

\begin{tabular}{cc}
\hline $\begin{array}{c}\text { Treatment of Gibberelin } \\
(\mathbf{p p m})\end{array}$ & $\begin{array}{c}\text { Chlorophyll Content } \\
(\boldsymbol{\mu g} / \mathbf{m l})\end{array}$ \\
\hline G0 (0) & 30.70 \\
G1 (50) & 38.20 \\
G2 (100) & 36.03 \\
\hline
\end{tabular}

In this study, gibberellin did not have a significant effect on chlorophyll content (Table 3). It is thought that gibberellin plays a greater role in the formation of leaf area. The chlorophyll content in the control (30.7) was lower than the plants treated with gibberellin. Gibberellin is a growth regulating substance that acts to stimulate the elongation of stem segments, is involved in the initiation of fruit growth after pollination (especially if auxin does not play an optimal role). The response to gibberellin includes increased cell division and cell enlargement. Giving gibberellin as much as $250 \mathrm{ppm}$ gave the best growth and yields on wheat cultivar dewata because it showed the highest seed weight per panicle and seed weight per plant [5], [10] also reported that the inhibitory effect of $\mathrm{NaCl}$ on several growth parameters and photosynthetic pigments in Hibiscus sabdariffa by inducing enzyme activity and increasing RWC (relative water content). The chlorophyll content in leaves varies from plant to plant. Chlorophyll content varies between various plant varieties within a single species. For example, in croton plants, the chlorophyll content of the red-borne croton, cobra, and local croton contains chlorophyll. Leaf age also affects the variation in chlorophyll content in plants [11].

\subsection{Number of stomata}

Table 4. Number of stomata of vetiver on the application of Gibberelin under salt stress condition

\begin{tabular}{cc}
\hline $\begin{array}{c}\text { Treatment of Gibberelin } \\
\text { (ppm) }\end{array}$ & $\begin{array}{c}\text { Number of Stomata } \\
\mathbf{( m m}^{\mathbf{2}} \mathbf{)}\end{array}$ \\
\hline G0 (0) & $278.33 \mathrm{c}$ \\
G1 (50) & $385.67 \mathrm{ab}$ \\
G2 (100) & $387.33 \mathrm{a}$ \\
\hline
\end{tabular}

Note: Numbers in the same column and row followed by the same letter are not significantly different at the $5 \%$ level based on the LSD test

Gibberellin treatment had a significant effect on the variable number of stomata. The results of the different test results for the average number of stomata in the gibberelin treatment can be seen in Table 4. Gibberelin gave a significant effect on the number of stomata aged 8 WAP. Gibberelin treatment of $100 \mathrm{ppm}(\mathrm{G} 2=387.33 \mathrm{~mm} 2)$ and $50 \mathrm{ppm}(\mathrm{G} 1=385.67 \mathrm{~mm} 2)$ increased leaf dry weight compared to without giving Gibberelin $(\mathrm{G} 0=278.33 \mathrm{~mm} 2)$ for 8 WAP observations. Gibberelin 100 ppm treatment was not significantly different from giving Gibberelin 50 ppm but was significantly different from giving gibberelin.

In this study, it shows that the number of stomata is increasing. This is because the number of stomata is a morphological characteristic that results from planting vetiver in saline soil treated with gibberelin. The increasing number of stomata indicates that the stomata on the leaves are 
dense, indicating that photosynthesis and transpiration have a major influence on these conditions. Based on [12], stomata are pores found in the epidermis of leaves and stems and play a role in the exchange of plant gas and water which further affects photosynthesis, transpiration and nutrient uptake [13]. Stomata size and density are two of several morphological characteristics of stomata that affect the relationship between plants and environmental conditions such as water status [14]. A decrease in stomata density can increase tolerance to drought stress in barley [14]. Low stomata density will reduce plant transpiration in an effort to prevent water loss from plants and save water uptake from the soil so that soil moisture is maintained without damaging the effect of taking nutrients from the soil and maintaining groundwater availability [15], [16], stomata density is one of the response parameters to drought stress, where the more stressed the plant is, the lower the stomata density.

\section{Conclusion}

Gibberelin under salinity stress conditions had a significant effect on the observed variables of leaf area, leaf dry weight and number of stomata. However, it did not show a significant effect on the amount of chlorophyll.

\section{Acknowledgements}

We are thank you to University of Muhammadiyah Sumatera Utara for profiding financial assistance in conducting this research. Contract number: 106/II.3-AU/UMSU-LP2M/C/2018.

\section{REFERENCES}

[1] R. R. Esyanti and O. Mardisadora, "Vetiver oil production from root culture of Vetiveria zizanioides," Int. J. Agric. Biosyst. Eng., vol. 7, no. 9, pp. 863-866, 2013.

[2] A. Rinarti and I. M. Kamil, "Penggunaan Tanaman Akar Wangi (Vetiveria zizanioides) untuk Menyisihkan Logam Timbal pada Tanah Tercemar Lindi Studi Kasus: Leuwigajah, Kota Cimahi," J. Tek. Lingkung., vol. 16, no. 1, pp. 21-30, 2010.

[3] W. Liu, J. Liu, M. Yao, and Q. Ma, "Salt tolerance of a wild ecotype of vetiver grass (Vetiveria zizanioides L.) in southern China," Bot. Stud., vol. 57, no. 1, pp. 1-8, 2016.

[4] N. R. E. Muliawan, J. Sampurno, and M. I. Jumarang, "Identifikasi nilai salinitas pada lahan pertanian di daerah Jungkat berdasarkan metode daya hantar listrik (DHL)," Prism. Fis., vol. 4, no. 2, 2016.

[5] A. Novita and L. A. M. Siregar, "Respon Pertumbuhan Dan Produksi Rosella (Hibiscus Sabdariffa L.) Pada Tanah Salin Dengan Pemberian Asam Salisilat Dan Giberellin (Ga3)," J. Pertan. Trop., vol. 2, no. 3, pp. 258-263, 2015.

[6] M. J. Seghatoleslami, "Effect of Salt Stress on Germination of Satureja hortensis L., Cichorium intybus L. and Cynara scolymus L.," Iran. J. F. Crop. Res., vol. 8, no. 5, pp. 818$823,2010$.

[7] F. Y. Wicaksono, T. Nurmala, A. W. Irwan, and A. S. U. Putri, "Pengaruh pemberian gibberellin dan sitokinin pada konsentrasi yang berbeda terhadap pertumbuhan dan hasil gandum (Triticum aestivum L.) di dataran medium Jatinangor," Kultivasi, vol. 15, no. 1, 2016.

[8] S. Setiawan and A. Wahyudi, "Pengaruh Giberelin Terhadap Pertumbuhan Beberapa Varietas Lada untuk Penyediaan Benih Secara Cepat," Bul. Penelit. Tanam. Rempah dan Obat, vol. 25, no. 2, pp. 111-118, 2016. 
[9] R. A. Hadi, "Pengaruh Konsentrasi Giberelin (GA3) Terhadap Perkecambahan Beberapa Varietas Padi Sawah Pada Cekaman Salinitas Tinggi," AGROSCRIPT J. Appl. Agric. Sci., vol. 1, no. 2, 2019.

[10] E. Ariani, "Pengaruh berbagai pengaturan jarak tanam dan konsentrasi giberelin (GA3) terhadap pertumbuhan dan hasil tanaman gandum (Triticum aestivum L.) kultivar dewata di dataran medium Jatinangor," Agric. Sci. J, vol. 2, no. 1, pp. 31-52, 2015.

[11] Y. Gogahu, S. A. Nio, and P. Siahaan, "Konsentrasi klorofil pada beberapa varietas tanaman Puring (Codiaeum varigatum L.)," J. MIPA, vol. 5, no. 2, pp. 76-80, 2016.

[12] H. Pirasteh-Anosheh, A. Saed-Moucheshi, H. Pakniyat, and M. Pessarakli, "Stomatal responses to drought stress," Water Stress Crop plants, pp. 24-40, 2016.

[13] L. E. Arve, S. Torre, J. E. Olsen, and K. K. Tanino, "Stomatal responses to drought stress and air humidity," in Abiotic stress in plants-Mechanisms and adaptations, IntechOpen, 2011.

[14] J. Hughes et al., "Reducing stomatal density in barley improves drought tolerance without impacting on yield," Plant Physiol., vol. 174, no. 2, pp. 776-787, 2017.

[15] R. S. Caine et al., "Rice with reduced stomatal density conserves water and has improved drought tolerance under future climate conditions," New Phytol., vol. 221, no. 1, pp. 371$384,2019$.

[16] R. S. Rahayu, R. Poerwanto, D. Efendi, and W. D. Widodo, "Cekaman Kekeringan Berat Mempengaruhi Keberhasilan Induksi Bunga Jeruk Keprok Madura,” J. Hortik. Indones., vol. 11, no. 1, pp. 13-23, 2020. 